\title{
Development Learning Sequence dalam Kemampuan Berhitung Operasi Bilangan Bulat Anak Diskalkulia
}

\author{
Azka Baqiyatul Haibah, Abdul Huda \\ Universitas Negeri Malang \\ E-mail : azkaalhaibah165@gmail.com
}

\begin{abstract}
Abstrak: Anak diskalkulia di SD Alam Ar Rohmah mengalami kesulitan pada kemampuan bahasa dan membaca yang berpengaruh dalam memahami simbol- simbol dalam matematika. Pendekatan development learning sequence merupakan pendekatan yang berdasarkan pada tahapan perkembangan anak dari konkret dengan menggunakan media nyata dan semi konkret dengan manipulasi gambar yang mampu menjembatani anak untuk berpikir abstrak. Tujuannya penelitian ini yaitu untuk mengetahui pengaruh pendekatan development learning sequence terhadap kemampuan berhitung operasi bilangan bulat anak diskalkulia kela VI di SD Alam Ar Rohmah. Metode penelitian dengan menggunakan Single Subject Research dengan desain A-B-A. Hasil penelitian menunjukkan presentase overlap sebesar 0\%. Kesimpulannya, pendekatan development learning sequence berpengaruh meningkatkan kemampuan berhitung operasi bilangan bulat anak diskalkulia kelas VI di SD Alam RohmahMalang.

Kata kunci: Diskalkulia, Pendekatan Development Learning Sequence, Berhitung
\end{abstract}

\begin{abstract}
Dycalculia children in SD Alam Ar Rohmah experience difficulties with language and reading abilities which are influential in understanding symbols in mathematics. The approach of development learning sequence is an approach that is based on the stages of child development from concrete with using real and semi concrete media with image manipulation that can bridge children to abstract thinking. The purpose of this study determine the effect of the development learning sequence approach on the ability of integer operation for dyscalculia children in the sixth grade at SD Alam of Ar Rohmah. Research method using Single Subject Research with A-B-A design. The results showed a percentage of overlap of $0 \%$. In conclusion, that the development learning sequence approach has an effect on increasing the ability to calculate integer operations in sixth grade of dyscalculia children in SD Alam Rohmah.
\end{abstract}

Keyword: Dyscalculia, Approach Development Learning Sequence, Calculating Integers Operations.

Salah satu komponen terpenting yang dijadikan acuan oleh satuan pendidikan adalah kurikulum. Kurikulum dikembangkan dengan mengacu pada standart nasional pendidikan demi mewujudkan tujuan pendidikan nasional yang telah ditetapkan. Berdasarkan UU No. 20 Tahun 2003 tentang Sistem Pendidikan Nasional pada pasal 37 disebutkan bahwa matematika merupakan salah satu kurikulum wajib yang harus dimuat dalam pendidikan dasar dan menengah selain pendidikan agama, pendidikan kewarganegaraan, bahasa, ilmu pengetahuan alam, ilmu pengetahuan sosial, seni dan budaya, pendidikan jasmani dan olahraga, ketrampilan, kejuruan serta muatan lokal. Dalam undang-undang tersebut dijelaskan pula, bahwa pengembangan kurikulum pada semua pendidikan berdasarkan pada prinsip diversifikasi, yaitu sesuai pada satuan pendidikan, potensi daerah dan peserta didik pada masing-masingdaerah.

Selain itu, Dewiyani (2009) menyebutkan matematika erat hubungannya dengan kehidupan sehari-hari. Tanpa disadari, hampir setiap aktivitas sehari-hari pasti menggunakan konsep matematika. Dari hal yang sederhana seperti, perhitungan jam, harga barang, sampai hal yang lebih kompleks lagi. Namun,apabila dilihat dari sudut pengklasifikasian bidang ilmu pengetahuan, pelajaran matematika termasuk dalam kelompok ilmu-ilmu eksakta yang lebih banyak memerlukan pemahaman daripada hafalan.

Cakupan dalam ilmu matematika pun sangat luas. Ilmu matematika menurut Kemendikbud (2007) dibagi dalam beberapa tingkatan. Dimulai dari tingkat yang paling sederhana, yaitu kemampuan dasar seperti klasifikasi (mengelompokkan), komparasi (membandingkan), seriasi (mengurutkan), serta simbolisasi (menyimbolkan) dan konservasi. Dilanjutkan sampai kemampuan kompleks yang sifatnya operasional seperti menentukan nilai tempat, operasi hitung penjumlahan, pengurangan, perkalian, dan pembagian. Runtukahu (2014) juga menjelaskan bahwa pengetahuan dalam matematika merupakan pegetahuan yang terstruktur dan saling berkaitan antara bagian satu dengan yang lainnya. Sebuah topik yang dipelajari mengalami keterkaitan dengan topik yang mendahuluinya. Apabila diibaratkan, apabila anak belum mengusai topik yang pertama, maka akan mengalami kesulitan dalam memahami topik selanjutnya dan begitu seterusnya.

Berdasarkan data yang diperoleh dari Trends In Internasional Mathematics and Science atau TIMSS 2015 yang diinisiasi oleh The International Association forthe Evaluation of Educational Achievement (IEA) 
pada bidang ilmu matematika, Indonesia menempati peringkat ke 45 dari 50 negara lain yang mengikuti dengan perolehan skor 397 poin. Secara keseluruhan, rerata Indonesia adalah $26 \%$, masih tertinggal jauh di bawah rerata Internasioanal yakni 50\%. Berdasarkan informasi dari Badan Penelitian dan Pengembangan (2015), salah satu faktor yang memiliki hubungan erat dengan pencapaian skor matematika adalah peran guru terhadap pemahaman kurikulum yang diajarkan. Bukan hanya pemahaman terhadap materi yang diajarkan, namun juga pada media, metode dan pendekatan yang digunakan dalam penyampaian materi. Pada umumnya, pendekatan yang digunakan dalam proses pembelajaran adalah secara klasikal. Berdasarkan studi kasus yang dilakukan di SD Alam Ar Rohmah pada kelas VI D, dalam materi pembelajaran operasi bilangan bulat guru menggunakan strategi menghafal kata kunci dalam penanaman konsepnya. Istilah yang digunakan adalah "KeJu BeKu dan SamPo BeNe" yang berarti kembarjumlahkan, beda-kurangi dan sama-positif, bedanegatif. Maksud dari istilah tersebut adalah dalam operasi penjumlahan dan pengurangan apabila kembar jenis bilangannya maka jumlahkan, namun apabila berbeda maka kurangi. Dan pada operasi perkalian dan pembagian apabila bilangan sama hasilnya adalah positif dan apabila bilangannya berbeda maka hasilnya adalah negatif.

Dalam mengidentifikasi awal anak kesulitan belajar (Sumarti, 2005) terdapat 25 instrumen. Apabila dari hasil pengamatan, menunjukkan lebih dari delapan item perilaku dalam daftar cecklis, maka kemungkinan anak tersbut berisiko mengalami kesulitan belajar. Berdasarkan identifikasi yang telah dilakukan pada bulan Mei 2018 di kelas VI SD Alam Ar Rohmah, terdapat satu siswa dari 16 siswa lainnya yang tidak dapat menuntaskan pembelajaran matematika dengan baik. Siswa tersebut diberikan pengamatan dalam 25 item perilaku serta beberapa soal dari materi penjumlahan dan pengurangan bersusun, operasi bilangan bulat serta perkalian dan pembagian.

Hasil identifikasi yang ditunjukkan pada lampiran 2 selama proses pengamatan diperoleh beberapa hal, diantaranya perhatian siswa tersebut mudah teralih dan cukup lambat dalam mengikuti instruksi. Siswa tersebut juga cukup sulit mengemukakan pendapat. Pada saat mengerjakan soal pengurangan bersusun siswa cenderung mengurangi semua bilangan yang lebih besar dengan bilangan yang lebih kecil, mengurangi tanpa memperhatikan teknik meminjam. Pada soal operasi bilangan bulat, siswa cenderung mengalami kesulitan pada penjumlahan bilangan negatif dengan negatif, pengurangan bilangan positif dengan positif (bilangan pengurang lebih besar), pengurangan bilangan positif dengan negatif, pengurangan bilangan negatif dengan positif serta pengurangan bilangan negatif dengan negatif. Selain itu siswa tersebut juga mengalami kesulitan pada operasipembagian.

Abdurrahman (2012) menjelaskan anak kesulitan belajar adalah anak yang mengalami kesulitan dalam menyelesaikan tugas-tugas akademiknya disebabkan karena adanya disfungsi neurologis yang menimbulkan adanya kesenjangan antara prestasi dengan potensi yang dimilikinya. Adapun kesulitan belajar akademik menunjukkan adanya kegagalan-kegagalan pencapaian prestasi akademik yang mencakup penguasaan dalam membaca, menulis, atau matematika. Dari hasil asesmen yang dilakukan sebagai bentuk tindak lanjut, dapat disimpulkan bahwa anak tersebut mengalami kesulitan belajar dalam bidang matematika.

Anak yang mengalami kesulitan belajar pada bidang matematika atau berhitung, memiliki kesulitan tersendiri dalam memahami konsep matematika. Kesulitan matematika atau berhitung mencangkup kesulitan dalammenggunakan bahasa simbol untuk berpikir, mencatat, mengkomunikasikan ide-ide yang berkaitan dengan kuantitas atau jumlah (Kemendikbud, 2007). Berdasarkan hal tersebut, metode klasikal yang digunakan oleh guru dengan menggunakan istilah "KeJu BeKu dan SamPo BeNe" tentu kurang cocok apabila diterapkan pada anak yang mengalami kesulitan belajar yang memiliki kesulitan dalam memahami simbol.

Pendekatan pembelajaran yang dapat berpengaruh bagi anak kesulitan belajar matematika dalam Abdurrahman (2012) dibagi menjadi empat, pertama adalah pedekatan urutan belajar yang bersifat pengembangan (development learning sequence), pendekatan ini dipengaruhi oleh teori perkembangan kognitif dari Piaget. Kedua adalah pendekatan belajar tuntas (master learning) yang menekankan pada pengajaran matematika melalui pembelajaran langsung. Ketiga yaitu pendekatan strategi belajar yan memusatkan pada pengajaran bagiamana belajar matematika (learning strategies) dan terakhir adalah pendekatan pemecahan masalah (problemsolving).

Pedekatan development learning sequences adalah pendekatan yang menekankan pada pengukuran kesiapan belajar siswa, penyediaan pengalaman dasar, dan pengajaranketerampilan matematika prasyarat. Teori ini menjelaskan perlunya pengajaran matematika dimulai dari benda atau peristiwa konkret menuju ke semi konkret baru akhirnya ke abstrak. Hal ini sejalan dengan teori Piaget. Anak MI/SD adalah anak yang pada umumnya berada pada kisaran umur 7-12 tahun, menurut Piaget dalam Suparno (2001) anak dalam usia ini masih berada pada tahap berpikir operasional konkrit, artinya bahwa anak usia MI/SD belum bisa berpikir formal atau abstrak. Pada tahap ini anak dapat memahami materi dengan menggunakan alat bantu media konkret atau dengan alat bantu semi konkret dengan menggunakan manipulasi gambar. Sehingga dalam pembelajaran matematika guru harus memperhatikan karakteristik peserta didik dalam melaksanakan pembelajaran dikelas.

Selain itu, studi pendahuluan yang dilakukan 
oleh Veronica Puspita Ningrum (2016) yang berjudul "Pengaruh Pendekatan Development Learning Sequences Terhadap Kemampuan Menjumlahkan Pada Anak Diskalkulia Kelas IV di SDN Sumbersekar III Dau" diperoleh kesimpulan bahwa pendekatan tersebut dapat meningkatkan kemampuan menjumlahkan pada anak diskalkulia. Berdasarkan hal di atas, maka peneliti tertarik untuk melakukan penelitian dengan menerapkan "Pendekatan Development Learning Sequence untuk Meningkatkan Kemampuan Berhitung Operasi Bilangan Bulat pada Anak Diskalkulia Kelas VI di SD Alam Ar- Rohmah Malang" sesuai tahap perkembangan anak.

\section{METODE}

Pendekatan yang digunakan dalam penelitian ini adalah pendekatan eksperimen kuantitatif dengan rancangan Single Subject Research (SSR) menurut Sugiyono (2010) metode eksperimen adalah metode yang digunakan untuk mencari pengaruh perlakuan tertentu (intervensi) terhadap yang lain dalam kondisi terkendalikan. Perlakuan yang digunakan dalam penelitian ini yaitu penggunaan pendekatan development learning sequence. Penelitian subjek tumggal (Single Subject Reseach) dipilih karena penelitian ini tidak digunakan untuk membandingkan kinerja antar kelompok melainkan membandingkan subjek yang sama dalam kondisi yang berbeda yaitu kelompok baseline dan intervensi.

Variabel bebas adalah penggunaan pendekatan development learning sequence dan variabel terikat dalam penelitian ini adalah kemampuan berhitung operasi bilangan bulat anak diskalkulia kelas VI di SD Alam Ar-Rohmah

Desain Penelitian, penelitian ini yaitu desain A-B-A yang terdiri dari tiga tahapan kondisi, yaitu kondisi baseline-1 (A1), kondisi intervensi (B), dan kondisi baseline-2 (A2). Kondisi awal baseline (A1) yaitu variabel terikat (kemampuan berhitung operasi bilangan bulat) diukur secara periodik atau sampai menunjukkan data stabil sebelum diberikan perlakuan. Pengukuran awal diukur menggunakan instrumen yang telah disiapkan oleh peneliti. Kondisi B yaitu intervensi terhadap variabel terikat (kemampuan berhitung operasi bilangan bulat) yang diukur selama pembelajaran dengan pendekatan development learning sequence. Setelah pengukuran pada kondisi intervensi (B) dilanjutkan dengan pengukuran kondisi baseline yang kedua (A2). Penambahan pada kondisi baseline diberikan, dimaksudkan sebagai kontrol untuk fase intervensi, sehingga memudahkan dalam menarik kesimpulan adanya hubungan antara pendekatan development learning sequence (variabel bebas) dengan kemampuan berhitung operasi bilangan bulat (variabel terikat).

Penelitian ini berlokasi di SD Alam Ar-Rohmah
Malang, yang mana disekolah tersebut terdapat peserta didik yang mengalami diskalkulia. Subjek penelitian yaitu berinisial AA berusia 12 tahun dan berjenis kelamin perempuan dengan hambatan diskalkulia.

Instrumen penelitian menggunakan lembar observasi dan lembar penilaian. Lembar penilaian digunakan untuk mengumpulkan data kemampuan berhitung meliputi, ketrampilan membilang, kemampuan mengoperasikan bilangan bulat dan kemampuan menentukan nilai hasil pada masingmasing soal dengan pendekatan development learing sequence pada fase baseline-1 (A1), intevensi (B), dan baseline-2 (A2). Pada lembar penilaian, data dikumpulkan dalam jenis ukuran presentase.

\section{HASIL DAN PEMBAHASAN}

\section{Hasil}

Hasil dari penelitian menemukan 2 hal penting, yaitu (1) mengetahui perbedaan kemampuan berhitung operasi bilangan bulat anak diskalulia kelas VI di SD Alam Ar-Rohmah Malang sebelum dan sesudah menggunakan pendekatan development learning sequence (2) pengaruh pendekatan development learning sequence dalam meningkatkan kemampuan berhitung operasi bilangan bulat anak diskalulia kelas VI di SD Alam Ar-RohmahMalang.

Baseline pertama pada penelitian ini yaitu melakukan pengukuran kemampuan awal subjek dalam kemampuan kemampuan berhitung operasi bilangan bulat sebelum diberikan intervensi. Pada kondisi baseline- 1 (A1) dilakukan observasi tanpa intervensi untuk mengetahui kemampuan awal subjek. Subjek penelitian dalam kondisi ini hanya diberikan lembar kerja. Adapun data baseline- 1 (A1) yang diperoleh dalam penelitian sampai trend data stabil adalah sebagai berikut :

Hasil pengukuran kondisi baseline-1 (A1) kemampuan berhitung operasi bilangan bulat anak diskalkulia yaitu pada sesi pertama mendapatkan nilai sebesar 33\%, sedangkan pada sesi kedua nilai yang diperoleh siswa menurun menjadi 30\%. Pada sesi ketiga dan keempat kondisi baseline- 1 (A1) nilai siswa menaik yaitu 33\%. Dari perolehan keempat skor ini menunjukkan kestabilan tingkat stabilitas yang cukup tinggi (tabel 4.7). Grafik 1 (hasil pengukuran kondisi baseline-1) menggambarkan kemampuan berhitung operasi bilangan bulat subjek sebelum diberi intervensi atau perlakuan.

Selanjutnya, pengukuran pada kondisi intervensi (B) dilaksanakan setelah subjek mendapatkan intervensi yaitu pendekatan development learning sequence. Fase intervensi (B) dilaksanakan selama 8 sesi. Adapun data pada kondisi intervensi (B) kemampuan berhitung operasi bilangan bulat yaitu pada sesi pertama mendapatkan nilai sebesar $67 \%$. 
Pada sesi kedua dan ketiga mengalami meningkatan nilai, yaitu $70 \%$ dan $73 \%$. Sesi keempat mengalami penurunan dengan memperoleh nilai $70 \%$, namun pada sesi kelima sampai kedelapan mengalami peningkatan dengan nilai $73 \%$ dan $77 \%$. Grafik 2 (hasil pengukuran kondisi intervensi) menggambarkan kemampuan berhitung operasi bilangan bulat saat diberi intervensi. Tahap penelitian selanjutnya adalah pengukuran kondisi baseline-2 (A2) yang dilakukan untuk mengetahui pengaruh intervensi (B) terhadap subjek penelitian. Pengukuran dilaksanakan selama 5 sesi. Pengambilan data diberhentikan ketika hasil nilai dari tiga sesi terakhir sudah stabil. Nilai stabil yang dimaksud yaitu jarak perolehan per-sesi tidak lebih dari 5,00. Dari hasil yang telah didapat, data dapat analisis dengan dua tipe yaitu analisis dalam kondisi dan analisis data antar kondisi.

Analisis dalam kondisi meliputi: a) panjang kondisi, b) estimasi kecenderungan arah, c) kecenderungan stabilitas, d) jejak data, e) level stabilitas dan rentang, f) perubahan level. Panjang kondisi yaitu pada baseline- 1 terdapat 4 sesi, pada kondisi intervensi terdapat 8 sesi dan pada kondisi baseline-2 yaitu 5 sesi. Selanjutnya, langkah-langkah dalam menentukan kecenderungan arah yaitu: 1) Membagi data pada 1 kondisi menjadi 2 bagian. 2) Bagian kanan dan bagian kiri menjadi 2 bagian dan tarik garis 2a. 3) Menarik garis sejajar dengan absis yang menghubungkan titik temu antara median kanan dan median kiri, Sunanto (2005). Berdasarkan tabel 1 bahwa estimasi kecenderungan arah kemampuan berhitung operasi bilangan bulat pada kondisi baseline-1, intervensi dan baseline-2 adalah menunjukkan peningkatan, dengan dilambangkan menggunakan tanda positif $(+)$.

Rentang stabilitas dalam penelitian ini yaitu pada kondisi baseline-1 diperoleh rentang stabilitas 4,95 dan mean level 32,25. Berdasarkan rentang stabilitas dan mean level maka diperoleh batas atas 34,725 dan batas bawah 29,775 dan memiliki kecenderungan stabilitas yaitu 100\%. Selanjutnya pada kondisi intervensi rentang stabilitas $100 \%$ dan mean level 72,5. Berdasarkan rentang stabilitas 10,5 dan mean level 67,4. Berdasarkan rentang stabilitas dan mean level maka diperoleh batas atas 72,65 dan batas bawah 62,15 dan memiliki kecenderungan stabilitas yaitu $100 \%$. dengan memberikan tanda $(+)$ jika meningkat, tanda (-) jika menurun dan tanda (=) jika mendatar atau tidak ada perubahan.

Menentukan jejak data sama dengan menentukan kecenderungan arah. kecenderungan jejak data kemampuan menulis permulaan pada baseline-1 yaitubernilai positif $(+)$ yang menandakan adanya peningkatan. Kecenderungan data pada intervensi (B) dan baseline-2 (A2) juga mengalami peningkatan yamg dilambangkan dengan tanda positif
(+). Selanjutnya yaitu menentukan level stabilitas sama dengan kecenderungan stabilitas dan rentang diambil dengan cara memasukkan dari masing-masing kondisi skor terendah sampai skor tertinggi. Pada penelitian ini yaitu, stabilitasnya yaitu pada kondisi baseline-1 (A1) adalah 30\% - 33\%, rentang stabilitas pada kondisi intervensi adalah $67 \%$ - 77\% dan pada kondisi baseline-2 rentang stabilitas yang diperoleh yaitu $63 \%$ $-70 \%$. Perubahan level dapat diketahui dengan cara menghitung selisih data sesi terakhir dan data pada sesi pertama setiap kondisi. . Setelah itu, ditentukan arah Selanjutnya yaitu masuk dalam analisis data antar kondisi meliputi: a) jumlah variabel yang diubah, b) perubahan kecenderungan arah dan efeknya, c) perubahan kecenderungan stabilitas, d) perubahan level, dan e) presentase overlap. Dapat disimpulkan yaitu : Jumlah variabel yang akan diubah adalah satu, yaitu kondisi baseline ke kondisi intervensi. Perubahan kecenderungan arah antara kondisi baseline-1 (A1) ke intervensi (B) adalah meningkat ke meningkat, kemudian kondisi intervensi ke baseline-2 (A2) yaitu meningkat ke meningkat. Perubahan kecenderungan stabilitas antara kondisi baseline-1 (A1) ke intervensi (B) dan kondisi intervensi ke baseline-2 (A2) adalah stabil ke stabil. Perubahan level antara kondisi intervensi (B) dengan baseline-1 (A1) sebesar 34\% dengan tanda positif $(+)$ yang berarti skor menunjukkan peningkatan, dan perubahan level antara kondisi baseline-2 (A2) denganintervensi (B) sebesar 3 dengan tanda positif $(+)$ yang berarti skor menunjukkan peningkatan. Persentase overlap adalah perhitungan data yang tumpang tindih dari baseline-1 ke intervensi adalah $0 \%$. Persentase overlap data intervensi ke baseline-2 tidak perlu dihitung karena baseline-2 bertindak sebagai kontrol. Berdasarkan hasil presentase overlap sebesar $0 \%$ ini menunjukkan bahwa pemberian intervensi atau perlakuan berupa pendekatan development learning sequence berpengaruh terhadap target behavior yaitu kemampuan berhitung operasi bilangan bulat. Pemberian intervensi berpengaruh terhadap target behavior karena dapat meningkatkan kemampuan berhitung operasi bilangan bulat anak diskalkulia kelas VI di SD AlamAr-Rohmah.

\section{Pembahasan}

Hasil penelitian pengaruh pendekatan development learning sequence terhadap kemampuan berhitung operasi bilangan bulat anak diskalkulia kelas VI menunjukkan bahwa pendekatan development learning sequnce memiliki pengaruh dalam meningkatkan kemampuan berhitung operasi bilangan bulat anak diskalkulia kelas VI di SD Alam Ar- Rohmah dengan subjek NN.Hal ini dapat diamati melalui hasil yang diperoleh pada setiap kondisi. 
Pada fase baseline-1 (A1) nilai kemampuan berhitung operasi bilangan bulat berkisar antara 30\% - 33\%. Kemudian pada fase intervensi dengan menggunakan pendekatan development learning sequence mengalami peningkatan yang cukup signifikan dengan nilai antara $67 \%$ - 77\%. Sedangkan pada fase baseline-2 (A2) sebagai fase kontrol nilai yang diperoleh antara 63\% - $70 \%$ yang juga mengalami peningkatan apabila dibandingkan dengan fase baseline-2(A2).

Hal ini diperkuat dengan hasil analisis data antar kondisi yang menunjukkan adanya peningkatan dalam kemampuan berhitung operasi bilangan bulat dengan menggunakan pendekatan development learning sequence. Perubahan kecenderungan arah dari fase intervensi ke fase baseline-1 (A1) menunjukkan arah yang meningkat yang berarti intervensi yang diberikan berpengaruh positif dalam kemampuan berhitung operasi bilangan bulat anak diskalkulia. Selain itu perubahan stabilitas dari fase intervensi ke fase baseline-1 (A2) menunjukkan perubahan dari kondisi stabil ke stabil. Demikian pula pada perubahan stabilitas dari fase baseline- 2 (A2) ke fase intervensi juga menjukkan perubahan stabilitas dari kondisi stabil ke stabil.

Hasil analisis antar kondisi juga diperoleh skor perubahan level yang dilihat dari nilai pada sesi akhir fase baseline-1 (A1) dengan nilai pada sesi pertama fase intervensi dengan selisih nilai sebesar

$+34 \%$. Skor perubahan level tersebut menunjukkan adanya peningkatan kemampuan berhitung operasi bilangan bulat dari fase baseline-1 ke fase intervensi. Mean level pada fase baseline-1 (A1) adalah 32,25\% dan meningkat menjadi $72,5 \%$ pada kondisi intervensi dan $67,4 \%$ pada fase baseline-2 (A2). Skor tersebut juga menunjukkan adanya peningkatan kemampuan berhitung operasi bilangan bulat sebelum diberikan intervensi dengan sesudah diberikan intervensi. Peningkatan kemampuan berhitung operasi bilangan buat anak diskalkulia setelah mendapatkan intervensi masuk dalam kategoritinggi.

Selain itu berdasarkan presentase overlap pada penelitian ini menunjukkan skor sebesar $0 \%$. Sunanto (2006) menyebutkan presentase overlap berbanding terbalik dengan pengaruh intervensi terhadap target behavior, "semakin kecil presentase overlap maka semakin besar pengaruh intervensi terhadap target behavior". Hasil ini dapat memberikan penjelasan bahwa pendekatan development learning sequence memiliki pengaruh yang cukup besar terhadap kemampuan berhitung operasi bilangan bulat anak diskalkulia kelas VI di SD Ar-RohmahMalang.

Secara umum kemampuan berhitung operasi bilangan bulat pada fase saat diberikan intervensi dan setelah diberikan intervensi mengalami peningkatan, namun pada fase intervensi sesi kedelapan terjadi penurunan skor kemudian meningkat kembali pada sesi kesembilan sampai akhir sesi. Salah satu kondisi yang menyebabkan penurunan skor subjek NN adalah karena suasana dan lingkungan kelas yang kurang mendukung. Sesi kedelapan dilakukan pada hari Sabtu saat KBM (Kegiatan Belajar Mengajar) di SD Alam Ar Rohmah adalah Student Care dengan kegiatan Market Day sehingga siswa yang lain melakukan pembelajaran di luar kelas. Suasana ini membuat konsentrasi subjek NN cukup terganggu dengan keadaan lingkungan di sekitarnya. Reys, dkk dalam Runtukahu (2014) mengemukakan dalam mengadakan operasi bilangan dibutuhkan beberapa prasyarat belajar matematika. Kemampuan tersebut meliputi: 1) ketrampilan membilang, 2) pengalaman konkret dan 3) kemampuan bahasa. Kemampuan ini kemudian dikembangkan dalam tiga aspek penilaian dalam penelitian ini,diantaranya: 1) aspek ketrampilan membilang, 2) aspek kemampuan mengoperasikan bilangan bulat, dan 3) kemampuan menentukan nilai tempat.

Setelah diberikan intervensi subjek menunjukkan peningkatan dalam ketiga aspek penilaian. Pada fase baseline-1 (1) presentase kemampuan mengoperasikan bilangan bulat sebesar $12 \%$ dari intrumen yang dapat diselesaikan oleh subjek, subjek masih memerlukan beberapa bantuan dalam menyelesaikan instrumen yang diberikan. Sedangkan pada fase baseline-2 (A2) subjek mengalami peningkatan menjadi 30\%. Hal ini ditunjukkan dengan kemampuan subjek dalam menyelesaikan intrumen yang diberikan secara mandiri. Sedangkan pada aspek kemampuan menentukan nilai tempat, pada fase baseline-1 (A1) subjek mendapatkan presentase $10 \%$ dari instrummen yang dapat diselesaikan oleh subjek. Subjek seringkali langsung melakukan operasi penjumlahan atau pengurangan tanpa memperhatikan positif atau negatif bilangan. Sedangkan pada fase baseline-2 (A2) subjek memiliki peningkatan sebesar $29 \%$ dengan kemandirian subjek dalam menyelesaikan soal.

Adanya peningkatan dalam kemampuan berhitung operasi bilangan bulat anak diskalkulia setelah diberikan intervensi berupa pendekatan development learning sequence ini sejalan dengan pendapat Mulyono (2010: 206) bahwa"salah satu pendekatan yang paling berpengaruh dalam pembelajaran matematika adalah dengan pendekatan development learning sequence yaitu pendekatan yang berdasarkan pada tahapan perkembangan". Berdasarkan pendapat di atas dapat disimpulkan bahwa pendekatan development learning sequence memiliki pengaruh dalam meningkatkan kemampuan berhitung operasi bilangan bulat anak diskalkulia kelas VI di SD Alam Ar- Rohmah Malang. 


\section{KESIMPULAN DAN SARAN}

\section{Kesimpulan}

Kemampuan berhitung operasi bilangan bulat anak diskalkulia meliputi mengoperasikan penjumlahan dan pengurangan bilangan positif dan negatif sebelum diberikan intervensi berupa pendekatan development learning sequence masih rendah. . Kemampuan ini terlihat dari subjek yang hanya mampu menyelesaikan 3 dari 10 soal penjumlahan dan pengurangan bilangan bulat yang diberikan. Penilaian pada aspek kemampuan mengoperasikan soal dan menentukan nilai hasil pada masing-masing soal masih sangat rendah, dikarenakan subjek masih banyak membutuhkan bantuan dalam menyelesaikan soal. Pada fase ini, subjek belum dapat membedakan antara bilangan positif dan negatif sehingga dalam menyelesaikan soal subjek hanya menjumlahkan angka pada soal. Berdasarkan temuan penelitian dan memperhatikan positif dan negatif bilangan Kemampuan berhitung operasi bilangan bulat setelah diberikan intervensi pada fase baseline-2 (A2) berupa penerapan pendekatan development learning sequnce mengalami peningkatan dari kondisi baseline-1 (A1). Hal ini ditunjukkan kemampuan subjek yang mampu menyelesaikan rata-rata 8 dari 10 soal penjumlahan dan pengurangan bilangan bulat yang diberikan. Penerapan pendekatan development learning sequence berpengaruh baik terhadap kemampuan berhitung operasi bilangan buat yang ditunjukkan dengan perolehan mean level pada kondisi setelah diberikan intervensi sebanyak 8 sesi sampai trend stabil dengan skor sebesar $67,4 \%$ yang termasuk dalam kriteria kualifikasi dengan kemampuan tinggi. Selain itu, perolehan hasil presentase overlap dari fase intervensi ke fase baseline-1 (A1) menunjukkan skor $0 \%$ yang berarti bahwa tidak terdapat data yang tumpang tindih antara keduanya. Sehingga dapat disimpulkan bahwa penerapan intervensi berupa pendekatan development learnng sequence meliki pengaruh dalam meningkatkan target behavior kemampuan berhitung operasi bilangan bulat pada anak diskalkulia kelas VI di SD Alam Ar- Rohmah.

\section{Saran}

Peneliti mengemukakan saran-saran sebagai berikut: (1) Rekomendasi untuk guru. Berdasarkan hasil temuan di lapangan, diharapkan guru dapat mengoptimalkan kemampuan berhitung operasi bilangan bulat anak diskalkulia dengan menerapkan pendekatan development learning sequence. Selain itu, guru juga dapat menggunakan pendekatan yang lain dalam meningkatkan kemampuan berhitung operasi bilangan bulat, seperti dengan pendekatan pembelajaran kooperatif tipe NHT. Pendekatan tersebut sesuai dengan penelitian yang dilakukan oleh Eka Mery Fatmawati tahun 20017 yang berjudul
"Pembelajaran Kooperatif Tipe NHT Berbantu Papan Bermagnet untuk Meningkatkan Pemahaman Operasi Bilangan Bulat Siswa Kelas VII SMP Negeri 9 Bitung", yang dapat disimpulkan bahwa terdapat peningkatan pemahaman terhadap operasi bilangan bulat pada subjek penelitian. (2) Rekomendasi untuk peneliti selanjutnya. Peneliti selanjutnya diharapkan mampu mengembangkan penelitian dengan variabel serupa dengan karakteristik yang berbeda ataupun dengan terget behavior yang berbeda. Selain dapat digunakan untuk meningkatkan kemampuan berhitung operasi bilangan bulat, pendekatan ini berpengaruh untuk meningkatkan kemampuan penjumlahan bersusun dua sampai tiga angka yang dilakukan oleh Veronica Puspita Ningrum pada tahun 2012 dengan judul penelitian " Pengaruh Pendekatan Development Learning Sequence Terhadap Kemampuan Menjumlahkan Pada Anak Kesulitan Belajar Kelas VI di SDN Sumbersekar III Dau" dengan hasil penelitian yang ditunjukkan dengan peningkatan kemampuan menjumlahkan yang cukup signifikan. (3) Orang tua dapat melatih kemampuan berhitung operasi bilangan bulat anak diskalkulia dengan menggunakan pendekatan development learning sequence yang terdiri dari tahapan konkret dengan menggunakan media, dilanjutkan pada tahapan semi konkret dengan media gambar kemudian dilanjutkan pada tahapan abstak dalam bentuk pemberian soal. Hal ini dilakukan untuk mengoptimalkan kemampuan berhitung anak diskalkulia.

\section{DAFTAR RUJUKAN}

Abdurrahman, Mulyono. (2012). Anak Berkesulitan Belajar: Teori, Diagnosis, dan Remediasinya. Jakarta: PT Rineka Cipta.

Arikunto, Suharsimi. (2013). Dasar-Dasar Evaluasi Pendidikan. Jakarta: Bumi Aksara

Badan Penelitian dan Pengembangan. (2007). Model Kurikulum Bagi Peserta Didik yang Mengalami Kesulitan Belajar. Jakarta: Badan PendidikanNasional.

Dewiyani. (2009). Karakteristik Proses Berfikir Siswa dalam Mempelajari Matematika Berbasis Tipe Kepribadian. 15(10), 481-492.Dari http://eprints. uny.ac.id/12295/.

Jamaris, Martini. (2014). Kesulitan Belajar: Perspektif, Asesmen dan Penanggulangannya Bagi Anak Usia Dini dan Usia Sekolah. Bogor: Penerbit Ghalia Indonesia.

Ningrum, V. P. (2016). Pengaruh Pendekatan Development Learning Sequences Terhadap Kemampuan Menjumlahkan Pada Anak Diskalkulia Kelas VI di SDN Sumbersekar III Dau. Skripsi tidak diterbitkan. Malang: Fakultas Ilmu Pendidikan Universitas Negeri Malang. 
Sugiyono. (2015). Metode Penelitian Pendidikan (Pendekatan Kuantitatif, Kualitatif dan R\&D). Bandung:Alfabeta.

Sumarlis, Vitriani. (2005). Kontribusi Aspek Motorik, Persepsi, dan Bahasa Terhadap Risiko Kesulitan Belajar (Identifikasi Dini yang Dilakukan Di Tingkat Prasekolah). Tesis tidak diterbitkan. Depok: Fakultas Psikologi UI.

TIMSS Infographic (2015). Pusat Penilain Pendidikan (online), (https://puspendik.kemdikbud.go.id/ seminar.upload/), diakses 4 April 2018. Tombokan, Runtukahu \& Kandou, Selpius. 2014. Pembelajaran Matematika Dasar Bagi Anak Berkesulitan Belajar.

Yogyakarta: Ar-Ruzz Media.
Undang-Undang Republik Indonesia No 20 Tahun 2003. Komisi Informasi (online), (www. komisiinformasi.go.id), diakses 6 Desember 2017.Universitas Negeri Malang. 2017. Pedoman Penulisan Karya Ilmiah (PPKI). Malang: UM Press. 